\title{
МЕТОДИЧЕСКИЕ АСПЕКТЫ ФОРМИРОВАНИЯ ИНКЛЮЗИВНОЙ КУЛЬТУРЫ В ОБРАЗОВАТЕЛЬНОЙ ОРГАНИЗАЦИИ
}

\author{
Леонова Ольга Анатольевна \\ доктор педагогических наук, профессор \\ ФГБОУ ВО «Северо-Восточный государственный университет»
}

\begin{abstract}
Аннотация: статья посвящена применяемым методическим приемам и способам в работе со студентами с особыми образовательными потребностями и/или особыми возможностями здоровья в период их социальнопсихологической адаптации к образовательной среде вуза.

Ключевые слова: обучающиеся с особыми образовательными потребностями и/или особыми возможностями здоровья, воспитание, социально-психологическая адаптация, методические приемы.
\end{abstract}

\section{METHODICAL ASPECTS OF THE FORMATION OF INCLUSIVE CULTURE IN AN EDUCATIONAL ORGANIZATION}

\section{Leonova Olga Anatolevna}

Abstract: The article is devoted to the applied methodical techniques and methods in working with students with special educational needs and / or special health opportunities during the period of their socio-psychological adaptation to the educational environment of the university.

Key words: students with special educational needs and / or special health opportunities, education, socio-psychological adaptation, methodical techniques.

Несмотря на события последних двух лет, связанных с существенными изменениями в деятельности образовательных организаций вследствие пандемии, актуальность обобщения педагогического опыта и поиск новых решений в формировании инклюзивной культуры в образовательной организации не теряет своей значимости. Тренд цифровизации, подводящий университеты к функционированию полностью или частично в виртуальной среде, обостряет поиск решений в этой области, так как сетевое пространство, обеспечивая социальную изоляцию, в свою очередь, стимулирует процессы создания в виртуальном пространстве образов и жизнедеятельности обучающихся, существенно расходящихся с их реальным существованием. 
Более того личностный потенциал обучающихся группы нормы и обучающихся с особыми образовательными потребностями и/или особыми возможностями здоровья (далее ООП/ОВ3) не пополняется реальным опытом социального взаимодействия и признания за каждым человеком права на самореализацию независимо от жизненных обстоятельств. Анализ педагогического процесса в вузах, особенно в 2020 году, показал, что он-лайн образование достаточно хорошо справляется с обеспечением процесса обучения, но не готово так же успешно реализовывать воспитание. Таким образом, накопленного педагогической наукой знания о формировании инклюзивной культуры в образовательной организации явно недостаточно для понимания совокупности педагогических условий, в которых обучающийся независимо от своего физического, психологического и иных состояний может успешно взаимодействовать с окружающим социумом в современном смешанном формате реальной повседневности, минимизируя риски искажений собственных статусов (физического, психологического, социального и др.).

В ходе исследования проблемы формирования инклюзивной культуры в образовательной организации на заключительном этапе мы уделили особое внимание методическим аспектам социально-психологической адаптации обучающихся с ООП/ОВ3, так как поиск технологических решений (цифровых ресурсов), на наш взгляд, находится в прямой зависимости от понимания их ограничений в осуществлении процесса воспитания, частью которого является социально-психологическая адаптация.

Анализ материалов, представленных педагогическим сообществом в

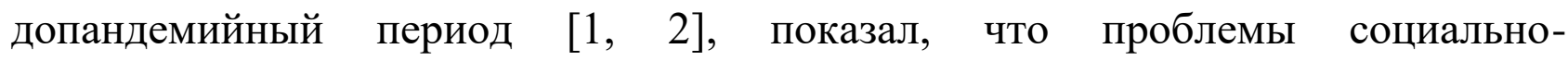
психологической адаптации обучающихся с ООП/ОВЗ в социальном пространстве вуза с учетом региональной и вузовской специфики не слишком отличаются от общих проблем этой категории лиц, среди них:

- наличие барьеров и ограничений в ориентировании и мобильности;

- трудности в освоении образовательных и профессиональных программ вуза;

- наличие личностных барьеров в овладении будущей профессиональной деятельностью и перед началом трудовой деятельности.

В связи с этим в качестве методических приемов и способов формирования инклюзивной культуры в организации нами реализовывались следующие:

- использование в течение учебного времени воспитательного потенциала аудиторных занятий, в том числе проведение, особенно на младших 
курсах, коррекционных упражнений, рекомендованных, например, в книге Е.И. Рогова «Настольная книга практического психолога в образовании» [3]. По мнению ряда ученых и практиков, системы диагностических и коррекционных методик, представленные этим автором, стали уже «классическими» в системе образования. Важным является и то, что применение этих методик разрешено не только психологам, но и разным категориям педагогических работников, что значительно повышает эффективность их работы с обучающимися с ООП/ОВЗ. Целесообразность ряда упражнений заключается в их полезности не только студентам с ООП/ОВЗ, но и для всей учебной группы. Преподаватель может составить программу использования упражнений в зависимости от специфики студентов с ООП/ОВЗ, которые обучаются в группе;

- использование воспитательного потенциала досуговой деятельности и разработка и реализация в учебной группе проектов «Толерантность» или «Достижения», которые позволяют объединить студентов в понимании определенного состава событий или явлений. Проект «Достижения» является первым опытом составления резюме, причем суть проекта состоит в том, что на первом этапе составляется резюме всей группы, а затем сами студенты определяют принадлежность тех или иных качеств/умений какому-либо обучающемуся, и студенты с ООП/ОВЗ - не исключение. Это лучше реализуется у студентов, обучающихся на 2-3 курсах;

- проведение кураторами групп, сотрудниками психологической службы или преподавателями занятий-тренингов на понимание студентами пространства другого человека (Я, Я-для-Другого, Другой-для-Меня).

Например, занятие-тренинг «Моя свобода в моей голове». Занятиетренинг проводится в рамках факультативного адаптивного курса или программы воспитательной деятельности, организуемых для студентов, обучающихся в смешанной инклюзивной группе.

Целевая аудитория: студенты 1 курса, в том числе студенты с ООП/ОВ3, в частности с нарушениями опорно-двигательного аппарата.

Требования к аудитории: желательно, чтобы в аудитории было как можно меньше столов с острыми углами и тяжелыми стульями. Лучше - круглый стол и легкие, но устойчивые, стулья.

Вспомогательные средства: мягкие шарфики, косынки, ленты, очки для сна (если есть студенты с нарушениями зрения, и занятие планируется, в том числе с учетом этой группы), беруши (если есть студенты с нарушениями слуха, и занятие планируется, в том числе с учетом этой группы). Все средства 
готовятся в количестве, равном количеству студентов.

Цели: актуализация эмоционально-чувственного восприятия студентами окружающего мира; совершенствование содержания ценностных ориентаций студентов, связанных с пониманием категорий «Здоровье», «Свобода», «Независимость», «Ответственность»; развитие умений и навыков рефлексивной работы.

Используемые технологии: социально-активные технологии, имитация ограничений в восприятии окружающего мира, рефлексивная методика «Кто Я».

Ход занятия. 1. Организационный момент. Краткое вступительное слово о целях проведения мероприятия, принятие правил. Начало тренинга. 2. Подготовительная часть: выявление фоновых знаний студентов о возможностях человека, об условиях, которые могут снижать эти возможности, об эмоциональном состоянии человека, осознающего эти условия; выявление субъективных ожиданий студентов (когнитивные, конативные, эмотивные и коммуникативные ожидания), направленных на себя и на других и связанных с периодом пребывания в вузе; подведение к выводу о ценности принятия себя и другого. 3. Интерактив. Студентам предлагается перевязать конечности, в том числе и студентам с ООП/ОВ3, и попробовать совершить ряд действий, в том числе учебных (перечень учебных действий составляет преподаватель в зависимости от специфики учебной группы). Студентам предлагается фиксировать свое состояние, эмоции, чувства и стараться это запомнить. Затем конечности высвобождаются по одной, и на каждом этапе вновь предлагается выполнить те же действия. Студентам разрешается сопровождать свои попытки комментариями. Следует отметить, что студенты с ООП/ОВЗ комментировали, что в некотором смысле не осознавали, что их возможности несколько шире. Затем студентам предлагается заполнить бланки методики «Кто Я» (первый бланк заполняется с учетом «связанного» состояния, второй бланк - с учетом $50 \%$ освобождения, третий бланк - состояние по завершении упражнения). 4. Заключительный этап - обсуждение, рефлексия полученного опыта.

Примененный на заключительном этапе контент-анализ позволил резюмировать выводы участников следующим образом:

- в части принятия другого: другой человек имеет свой Мир, и он другой; другой человек также наделен правом чувствовать собственную жизнь; другим могу стать я сам; каждый имеет право на свое пространство и имеет возможность поделиться им с другими;

- по совершенствованию содержания ценностных ориентаций 
студентов: «Здоровье» в части принятия любого человека и его состояния, принятия себя и своих несовершенств, «Свобода» в части понимания, что физические ограничения могут изменить темп активности человека, но не могут отменить его выбора той жизни, которую он хочет вести, «Независимость» в части изучения всех возможностей, которые предоставляются физически, и тех, которые способствуют постановке цели и ее достижению, уверенность в своих силах; «Ответственность» в части оказания или принятия сопровождения и поддержки людям с ООП/ОВ3;

- в части личностного опыта: анализ собственного опыта в принятии особенностей жизни другого человека и себя - основа саморазвития и самосовершенствования человека.

В методическом плане результаты занятия-тренинга суммируются в:

- формулировании учебных действий обучающихся (опережающий учебный эффект занятия);

- повышении мотивированности студентов к теоретическому и углубленному изучению ООП/ОВ3, а также к работе с людьми с ООП/ОВ3 (когнитивный эффект);

- предложениях студентов по совершенствованию комплексов подобных занятий, направленных на понимание другого человека (коммуникативный эффект).

Эффективность применения перечисленных методических приемов и способов была неоднократно подтверждена в ходе экспериментальной работы на протяжении длительного времени, в том числе и в современной архитектонике образовательного процесса, как одного из компонентов модели формирования инклюзивной культуры в образовательной организации. Деятельное обращение к личному и социально-культурному опыту студентов, в том числе студентов с ООП/ОВ3, приводит к получению ими личностно- и профессионально значимого знания, способствующего мотивированному поведению студентов в нестабильных социальных условиях жизнедеятельности.

Обобщение педагогического опыта и анализ конференционных публикаций свидетельствуют, что на современном этапе развития инклюзивной культуры в образовательных организациях в целях оптимизации процесса профессионального самоопределения студентов с ООП/ОВЗ методически целесообразны:

- адаптация программ профориентационной работы к потребностям студентов с учетом их психофизиологических особенностей, вплоть до 
индивидуализации этих программ под каждого обучающегося;

- начиная с первого курса, выстраивание индивидуальных образовательных траекторий этих студентов с результативностью трудоустройства;

- развитие мотивации к обучению, в том числе предложение вариативных адаптивных модулей, среди которых должно быть отведено место для практико-ориентированных, например, как составить резюме, как искать и находить работу, как формировать портфолио и др.;

- развитие в вузе информационных площадок взаимодействия с работодателями, общественными организациями и т.п. посредством соответствующего программного обеспечения (конференцсвязь, вебинары, телемосты и др.), а также проведение ответственного консультирования под руководством представителей работодателей;

- осуществление профессионального консультирования, в целом усиления компонентов профориентационной работы;

- повышение квалификации сотрудников, занимающихся вопросами профессионального самоопределения студентов с ООП/ОВ3;

- поиск спонсоров или участие в грантовых конкурсах для получения средств для повышения мобильности этой группы студентов;

- системная работа с родителями или их законными представителями.

Отметим, что, вероятно, не существует универсальных путей формирования инклюзивной культуры. Специфика методических решений в том, что каждая образовательная организация будет исходить из комплекса условий, свойственных именно ей (качество образовательной среды), а также из количества и особенностей самих студентов. Так, например, особое значение в нашей практике мы уделяем абитуриентскому составу и студентам первого года обучения.

Сложно выделить из накопленных лучших российских практик работы с абитуриентами с ООП/ОВЗ универсальные, так как каждая из них занимает свое место в системной работе с абитуриентами этой категории. Но, полагаем, что методически целесообразно начинать знакомство с этой потенциальной категорией студентов как минимум за два года до их поступления в вуз. Вузу следует своевременно получить информацию о будущих абитуриентах, провести первичные мероприятия с целью определения комфортных условий контактной работы. Это достигается проведением соответствующих подготовительных программ на базе школ и с использованием цифровых 
ресурсов, так как позволяет, с одной стороны, сохранить психологическую комфортность этой категории обучающихся, a, с другой стороны, установить социальную доступность преподавателей вуза, расширяя тем самым представления абитуриентов и их родителей о возможностях вуза. Также определенную роль играет включение этой категории учащихся в некоторые события жизни вуза. Как показывает практика, приглашение школьников на студенческие праздники, участие школьников на этапах довузовской подготовки в олимпиадах наравне с первокурсниками значительно помогают результативности последующих мероприятий. Также большое значение имеет профессиональное консультирование и профориентационное тестирование с участием психолога, педагога и представителя соответствующего лечебного или специального учреждения, в наилучшем случае - лечащего врача или семейного доктора.

Мы находимся в ситуации, когда юридически право на образование и его доступность закреплены в законодательных актах и иных документах, но практика инклюзивного образования еще не обеспечена соответствующим образом ни на одном уровне образования, начиная с дошкольных образовательных учреждений. Мы занимаемся в основном адаптацией того, что предназначено для условно здоровых детей и взрослых, для категорий обучающихся с ООП/ОВЗ, отклонения в здоровье которых не касаются интеллектуальной сферы. Поэтому наиболее значимое место в комплексе методических решений занимает индивидуализация каждой рекомендации по каждому абитуриенту с ООП/ОВ3, особенно в сфере социального коммуницирования, так как для полноценного функционирования в обществе этой категории нужно понимание своей собственной жизни как ценности, а не просто включение в жизнь людей группы нормы как разрешение на жизнь.

Проблемное поле, обсуждаемое в работах $[4,5,6,7,8]$, дополняется нами проблемами, с которыми сталкивается студент с ООП/ОВЗ на первом этапе обучения в вузе, а именно: проблема несовпадения субъективных ожиданий студента с реальной ситуацией образования, что влечет за собой, как минимум, рассогласование его мотивации и целей образования, выраженных в ожидаемых результатах образовательной программы; проблема неготовности к выбору образовательных предпочтений вследствие несформированности или недостаточной сформированности представлений о собственных реальных возможностях и интересах; проблема, обусловленная замедленным темпом коммуникаций, которая может перерасти в трудности социальных 
взаимодействий. Для их разрешения в ходе реализации индивидуальной профессиональной траектории студентов с ООП/ОВ3 преподаватели и кураторы групп осуществляют консультирование, проводят анализ и составляют прогноз профессионального самоопределения, применяют методики вариативного образования с подбором адекватных форм и методов профессионального становления студентов с ООП/ОВЗ посредством учебного материала и воспитательных взаимодействий.

Представленный нами комплекс методических приемов и способов, сопровождающих формирование инклюзивной культуры в образовательной организации, не является исчерпывающим. Нами приведена та его часть, которая неоднократно подтверждала свою эффективность независимо от изменяющихся условий внешней и внутренней среды организации. В свою очередь, они не являются универсальными, но степень их вариативности не влияет на конечный положительный результат. Позитивное взаимодействие с окружающим социумом, ориентирование в процессе развития собственной личности, ориентирование в видах занятости студентов в университете, овладение навыками распознавания личных мотивов и соотнесения их с мотивами других людей - далеко не полный перечень характеристик, достигаемый обучающимися с ООП/ОВЗ, когда педагогический коллектив с должным вниманием относится к методическим аспектам внедрения моделей инклюзивной культуры в образовательных организациях.

Надо полагать, что перечень методических приемов и способов в этой области будет пополняться, так как ландшафт образования и профессионального становления студентов в связи с цифровизацией стремительно изменяется, как и условия повседневной жизни россиян.

\section{Список литературы}

1. Инклюзивное образование: опыт, проблемы, перспективы: Сб. науч. трудов по материалам Всероссийской науч.-практ. конф. 19 ноября 2015 г., г. Стерлитамак, Республика Башкортостан / Отв. ред. Л.Б. Абдуллина, науч. ред. Т.И. Петрова - Стерлитамак : Стерлитамакский филиал БашГУ, 2015. - 207 с.

2. Инклюзивное образование: теория и практика [Текст]: сборник материалов международной научно-практической конференции /отв. ред. О.Ю. Бухаренкова, И.А. Телина, Т.В. Тимохина. - Орехово-Зуево: Редакционноиздательский отдел ГГТУ, 2016. - 955 с. 
3. Рогов Е. И. Настольная книга практического психолога в 2 ч. / Е. И. Рогов. - 4-е изд., перераб. и доп. - Москва : Издательство Юрайт, 2019. $412 \mathrm{c}$.

4. Евдокимова В.В. Адаптация студентов с ОВ3 к новому образовательному пространству как одно из направлений работы психологической службы СПК МГППУ // Инклюзивное образование: методология, практика, технологии. https://psyjournals.ru/inclusive_edu/ issue/44224_full.shtml (дата обращения: 14.01.2021).

5. Пряничникова О.Н., Прохорова Г.Е., Морозова Н.В., Брязгин А.С., Ковалев Д.С. Организация и проведение образовательного процесса для обучения лиц с ограниченными возможностями здоровья в образовательных организациях среднего профессионального образования Московской области//Сб. научно-методических материалов / О.Н. Пряничникова, Г.Е. Прохорова, Н. В. Морозова, А. С. Брязгин, Д. С. Ковалев. - Москва: АСОУ, 2015. $-78 \mathrm{c}$.

6. Рымханова А.Р., Тебенова К.С., Мусеева Г.Н., Сериков Т.Ш., Баянов М.А. К вопросу готовности преподавателя вуза к обучению студентов с особыми образовательными потребностями // Международный журнал прикладных и фундаментальных исследований. - 2016. - № 3-4. - С. 673-676; URL: https://applied-research.ru/ru/article/view?id=8958 (дата обращения: 11.01.2020).

7. Скамьянова Т. Ю. Адаптация студентов-первокурсников с особыми образовательными потребностями к обучению в вузе как педагогическая проблема // Управление образованием: теория и практика. 2019. №1 (33). URL: https://cyberleninka.ru/article/n/adaptatsiya-studentov-pervokursnikov-s-osobymiobrazovatelnymi-potrebnostyami-k-obucheniyu-v-vuze-kak-pedagogiches kayaproblema (дата обращения: 11.11.2020).

8. Шувалова И. Н., Богинская Ю. В. Адаптация студентов с ограниченными возможностями здоровья к обучению в вузе // Гуманитарные науки. 2015. №4 (32). URL: https://cyberleninka.ru/article/n/adaptatsiya-studentovs-ogranichennymi-vozmozhnostyami-zdorovya-k-obucheniyu-v-vuze (дата обращения: 11.01.2020).

(C) О. А. Леонова, 2022 